\title{
Abdur Rahman Shukri and his Romantic imagination on love poetry
}

\author{
Md. Atowar Rahman \\ Research Scholar, Department of Arabic, Assam University, Silchar, Assam, India-788011
}

\begin{abstract}
One of the most well known writers and a pre-Romantic poet of Diwan group and an innovative critic Abdur Rahman Shukri was born in Alexandria (1886-1958). Throughout the formative phases of Abdur Rahman Shukri's life, many figures were responsible for shaping his love and imagination on poetry. The purpose of this paper is to analyze the love and imagination on Shukri's poetry. Imagination is regarded as a tool of insight into a higher order of reality which many render those who have glimpsed it in capable of coping with this mundane world. Shukri's love poetry is marked by its excessive idealization of the beloved. Shukri addresses the beloved in the traditional masculine form, and occasionally uses conventional love and imagery. He has an unmistakable tendency to express himself in generalizations, sentiments and moral perception in the manner of traditional gnomic verse and his intellectual ability as manifested in his writings.
\end{abstract}

Keywords: Abdur Rahman Shukri, contribution to Arabic poetry, love and imagination, theme and styles

\section{Introduction}

Abdur Rahman Shukri was a Romantic poet. He was also a distinguished Egyptian poet of modern Arabic literature. He was the member of Diwan group who is remembered primarily for his poetry. A pre romantic poet member of Diwan group and an innovative critic Abdur Rahman Shukri was born in Alexandria in 1886. His primary education finished in 1900. After he entered the secondary school in Alexandria after then he entered the law school. He graduates of the Teacher Training College in Cairo. ${ }^{[1]}$ As from 1913 Shukri worked as a teacher at various secondary schools in Alexandria, including Ra'al- Tin and al-Abbasiyah. After a short period as principal of some secondary schools, he was an inspector at the Ministry of education from 1934 to 1938 , when he retired. Later he wrote some articles about his teaching period which contradict general assumption that teaching to him were permanently frustrating. After his retirement he return to Port Said and went to live with one of his brother. In 1952 he had a stroke which paralyzed his right side. In 1955 he moved to Alexandria. In 1956 a special issue of the magazine al-Alam al-Arabi was devoted to him. His father was an army officer, who took part in "Urabi", revolution in Egypt. ${ }^{[2]}$

Abdur Rahman Shukri studied the books in very anxiously when he was secondary student, so his teacher Sheik Abdullah Nadim is pleased. He enters the law college, but was soon sent down because of his political activities on behalf of the national party. So he comes into literature. He contributed many Arabic poems to Arabic literature. His romantic imagination is regarded as a stool of insight in to a higher order of a reality, the poem clearly shows ambivalent attitude to imagination. His main themes of his poetry are philosophical and moral meditations interesting or unusual states of mind, beauty in general and nature in particular love, death and creative imagination. Shukri's poetical style remains in many respects traditional the vocabulary is still quite difficult, requiring a glossary, and the verses does not flow smoothly enough for the particular themes it tries to express. He enter the teachers Training college in which he joined later he developed Arabic and English literature.

\section{Shukri's Contribution To Arabic Poetry}

Abdur Rahman Shukri was a romantic poet. He was an innovative critic of $20^{\text {th }}$ century in Arabic poetry. He was a member of light of the Diwan movement that heralded romanticism in Arabic. In 1909 Abdur Rahman Shukri published his first Diwan entitled 'Daw' al-Fajr' (the light of Diwan). Shukri published his writings on the poetic concept in Al-Bayan, Al-Jarida, Al-Muqtataf and afterwards in Apollo. He also wrote a forward to most of his Diwans in which he discussed poetry and poetic standards. He published his first Diwan in 1909 before spending three years in England at Sheffield University College. After his return to Egypt in 1912, five further volumes of poetry were published in rapid succession between 1913 and 1918; both in the poetry itself and particularly in the prefaces that he wrote to these collections, he reveals a deep and wide ranging knowledge of poetry and criticism in $18^{\text {th }}$ and $19^{\text {th }}$ century England. ${ }^{[3]}$

And while still a student he contributed to the modernist paper of the time Al-Jarida, which was edited by Latifi al-Sayyid who encouraged promising young authors like Muhammad Hussain Haykal and Taha Hussain. ${ }^{[4]}$ After he had published his first volume of verse, the light of Diwan in 1909, he sent on an 
educational mission to England, where he acquired a deeper knowledge of English literature at Sheffield University College. On his return in 1912 he was appointed teacher in secondary School in Alexandria, he remained in the field of education until his retirement in 1944, his second volume of verse was published in 1912, also with on introduction by Al-Aqqad, the best volumes followed in rapid succession and by 1919 the seventh and last volumes of his collected poems or Diwan called "Azhar al- Kharif" (Autumn flowers) had appeared.

Abd al- Rahman Shukri wrote of his poetry early in his career for study until his death in 1958, he published poems in literary periodical, but never a whole volume of verse. Besides his poetry he produced a number of prose works, the most interesting of which is short book of remarkable frankness, called the book of confessions (1916), a book full of profound self analysis and acute observations on art and man, life and death, and graphically expressing the malaise of the Egyptian intellectual at the beginning of the century. Shukri However did not acknowledge his authorship of the book of confessions but he attributed it to an imaginary friends M.N. ${ }^{[5]}$

It is clear, however that the author of the confession is none other than Abdur Rahman Shukri himself. Al-Mazini saw the point at once, and he later made use it in the severe attack he launched on him when tried to prove Shukri's madness. After this attack, but not entirely because of it, Shukri gradually withdraws within himself, cutting off from the literary society of his time. His pessimism had the better of him, and he was driven to near silence and the spent was almost completely broken. The poems published by his editor as the eight volumes in his collected poems (Diwan) in 1960. ${ }^{[6]}$

His main concern was in poetry than criticism. The main themes of his poetry are philosophical and moral meditations interesting or unusual states of mind, beauty in general and nature in particular love, death and creative imagination. He wrote the elegies on the nationalist leaders Mustafa Kamil, Qasim Amin and Muhammad Abduhu. His poem in the collection "Choruses and the captured women" opens with and address to young women. Shukri complains strongly of the lifeless artificial nature of contemporary Arabic poetry and scorns the age-old imagery.

\section{Love And Imagination}

Abdur Rahman Shukri's love poetry is marked by its excessive idealization of the beloved. In "Smiles" we read that her smile brightens up his soul and nearly unveils the unknown secrets of the invisible world, enables him to hear myriad songs in his soul, and her glance breaths life in him as the sun causes the hidden seeds to germinate. The terms in which she is described suggest that she is more than a more human being. In the beloved the lover's attitude is one of utter humility. ${ }^{[7]}$ He addresses her in I have no other concern but you saying

My soul is sapling which you planted and my soul is the lowly earth beneath your heights you are the target of all creatures, no one lives but you so have mercy upon me, my beloved. ${ }^{[8]}$

In "Love and eternity" the poet's love is love of beauty and not of individual human being. But although he claims I am not one who loves fair maidens, or do any eyes shed tears when they desert me (love and affection), there are moments when the passion seems to be human being. For instance, in the deeply moving a lover turns away his glance, the poets is agonizingly aware that object of his desire is, for some mysterious reason which he dares nay disclose, unattainable and that he therefore ought not to indulge daydreams about him or her, could it be that the poet was suffering from a homosexual passion. This is not at all a fantastic theory, although Shukri's general tendency to use to the traditional Arabic masculine pronoun in his love poetry cannot helps us to decide either way. However, we do know that Shukri never married, and what is more interesting there is morbid fascination with death and the gruesome aspects of physical decay and dissolution in practically all his love poems, especially where beautiful women are mentioned. ${ }^{[9]}$

Abdur Rahman Shukri's powerful poem is, 'Beauty and death' it is troubled and unable to sleep, sees in the dark of night embraces her once more dies in his arms, her beauty vanishes and her flesh disintegrates, leaving behind a skeleton smelling strongly of decay, the image of the poet kissing a dead corpse occurs again in his poetry. In women in life and in death, he sees the ugly and the dead behind beautiful and living, expressing a somewhat diseased sensibility. ${ }^{[10]}$

In his prose work "kitab al-Thamarat" (book of fruit) a book of meditations sometimes couched in poetic on man, nature, society and art, some defines love as an animal whose upper half is a beautiful women and whose lower part is a serpent. ${ }^{[1]}$

His every poem on love beauty ends with thoughts on death examples are so many that they can be chosen at random. One poem is given the "Al hub wal Maut" (love and death) others like beauty the "Mirror of nature" love's paradise and hell and "the end of love" and "after beauty" and particularly the last two show the poet facing the most unpleasant aspects of physical decay. ${ }^{[12]}$

He loves death as man love the face of his beloved and years to quench his passion by kissing its lips. And of course it is fairly often that the poet invokes death. In the misery of life, as the title suggests, the poet is writing 
about his suffering. Though living amidst his people he feels as if he had come to them from another planet, new and strange. Tired of his life he calls upon death to relive him, although death here is viewed in romantic pleasurable terms. Moonlight on the tombs depicts the moon as weary and wan, inspiring similar sensations in the holder, and likens it to a fair maiden worn out by disease and lying on her death bed. In "the voice of the death" the poets stands amidst the tombs and hears the voices of the dead sounding now like the resulting of wind in leaves, or the pub ling of water, now like the beating of drums, the wailing of bereaved women, the howling of desert wolves or the roaring of the enraged sea. "Between life and death" given us the lonely figure of poet standing by the raging sea in the middle of thunder storm on a dark night, a perfect sublime setting for the poet whose thoughts turn to the subject of death and suicide he admits to love of death being an overwhelming secret disease and addresses the sea. ${ }^{[13]}$

He explains that the secret of his unhappiness is a great sorrow deeply seating in his heart, he feels that the wide world is too confined for him and that he is buried alive. It is as if in his sleep his relations, mistaking him for dead, buried him in a deep grave and piled earth and stone on top him and the poet woke up not knowing whether he was awake or had just had a nightmare.

Finally, his well known dream of resurrection is a macabre poem giving the gruesome details of physical dissolution and betraying his low opinion of men, for it shows the persistence of human agreed and strife when the bodies, risen from their graves, quarrel over the missing limbs and parts on the day of resurrection.

Abdur Rahman Shukri even wrote a poem entitled "llai Majhuj" (To the unknown) a word which become very potent in romantic vocabulary' which shows this fascination (the patently didactic and moralistic prose introduction to the poem in which he links this passion to the healthy and useful scientific curiosity was added more than twenty years later). A painful mystery and a riddle yarning for communication with its like through love, without which he becomes an arid desert without water or vegetation, in "in paradise" a poem seen by one scholar to be intimately related to D.G Rosettes The Blessed demote on the one hand and to the Moslem tradition of the Heavenly Bride, hour, on the other, the poets cannot be happy if he divorced from his soul mate. Hence the poet's constant quest for the ideal object of his desire the poet and the image of perfection depicts a poet who in the pursuit of the ideal which is ultimately perfect beauty the creation of his imagination is lured to his destruction. ${ }^{[14]}$

Imagination is regarded as a tool of insight into a higher order of a reality, however, which may render those who have glimpsed it incapable of coping with the mundane world. The poem clearly shows Shukri's ambivalent attitude to imagination. He is both fascinated and frightened by it: lost is the man whose fancy in his guide, it was left for later. Younger generation of more through going romances to accept imagination without any reserve. In the mouthpiece of the invisible true imagination is said to be the mouthpiece of the invisible, and because the poet feels and suffers he sees what others cannot see and communes with the divine love. ${ }^{[15]}$

\section{Themes And Style}

Abd-Rahman Shukri can be a more cheerful as in his description, there are perhaps too many poems about the themes of idealized love in Shukri's work, and their cumulative effect tend to be rather monotonous, especially as the tome is generally solemn and unrelieved by any humor. Furthermore, they are mostly in the first person. There is no enough variety in them which could have been achieved if the poet he made a greater use of the narrative and dramatic poems. Not lat Shukri's poetry is entirely lacking in formal variety. He uses narrative and the dramatic monologue deriving his material from well known pre-Islamic Arabic stories and legends, or from more modern sources. He experiments in the use of the multiple rhymes, the alternative rhyme or rhyming complete. He even attempts to write blank (rhyme less) verse on a number of occasions, though the result cannot be described as successful, and in one case he finds himself slipping into monorhyme in eleven consecutive lines the poem which adheres to the monorhyme and monometer remains Shukri's norms.

Abdur Rahman Shukri stylistically, too, despite the profound influence of English romantic poetry on him, Shukri's style remains in many respects traditional the vocabulary is still quite difficult, requiring a glossary, and the verse does not flow smoothly enough for the particular themes it tries to express. As has already been mentioned Shukri addresses the beloved in the traditional masculine form, and occasionally uses conventional love and desert imagery. He has an unmistakable tendency to express himself in generalizations, sentiments and moral precepts in the manner of traditional gnomic verse. Once or twice when a young man he talked about his great ambition he struck the note of traditional boastfulness. He sometimes complains of his times in the manner of Mutanabbi, and even in a poem expressing envy, a specifically modern disease, we hear verbal echoes from Mutanabbi's verse. It is true that Abdur Rahman Shukri can attain a high degree of lyricism, as in his most accomplished poem. "The bird of paradise" but this does not happen frequently enough. On the contrary, he can easily descend to the level of what is largely poetry of more statement even in a poem about a romantic theme, as the ideal, which is an unabashed detente of the infinite inner world of terms and the imagination against the Arab and limited external reality. 


\section{Conclusion}

Abdur Rahman Shukri has a good deal of honesty and insight into his own character. There is no doubt that Shukri's malaise was in part reflection of the malaise of contemporary Egypt, caught as it was in the class between tradition Islamic and Western values in a period of cultural transition. But equally Shukri's own psychological makeup contributed to it. He begins with the assumption that happiness and great sensibility are mutually exclusive that a man of feeling is inevitably a man of suffering that the taste of masses in poetry and the fine arts is corrupt and that the conventional poetry of eulogy, elegy, satire and description of daily political and social occurrence, in the short the poetry of establishment at the time, is poetry of the false heart and that the true poet, described the passion of the soul to modern Arabic literature.

\section{References:}

[1]. Dr.Daif, Shawqi, Al-Adab-al-Arabi-al-Muashir fi-Misr, Cairo, p-128

[2]. Brugman, J, An introduction to the history of modern Arabic literature in Egypt, Leiden, 1984, p-115

[3]. Badawi, M.M. Modern Arabic literature, Cambridge University press, 1992, p-87

[4]. Dr.Daif, Shawqi, Al-Adab-al-Arabi-al-Muashir fi-Misr, Cairo, p-128

[5]. Badawi, M.M. A critical introduction to modern Arabic poetry, Cambridge University press, 1975, p-81

[6]. Dr.Daif, Shawqi, Al-Adab-al-Arabi-al-Muashir fi-Misr, Cairo, p-130

[7]. Badawi, M.M. Modern Arabic literature, Cambridge University press, 1992, p-94

[8]. Shukri, Abdur Rahman, Diwan, p-177

[9]. Shukri, Abdur Rahman, Diwan, p-269

[10]. Badawi, M.M. A critical introduction to modern Arabic poetry, Cambridge University press, 1975, p-100

[11]. Badawi, M.M. Modern Arabic literature, Cambridge University press, 1992, p-94

[12]. Dr.Daif, Shawqi, Al-Adab-al-Arabi-al-Muashir fi-Misr, Cairo, p-133

[13]. Badawi, M.M. A critical introduction to modern Arabic poetry, Cambridge University press, 1975,p-101

[14]. Badawi, M.M. A critical introduction to modern Arabic poetry, Cambridge University press, 1975,p-102

[15]. Badawi, M.M. Modern Arabic literature, Cambridge University press, 1992,p-94 